ice when they set off for the fishing grounds, each boat taking about 15 tons when going to fish in the North Sea and four times as much when fishing in Icelandic waters. In the Metropolitan-Vickers Gazette for March and April, J. H. Lamb gives an interesting account of the electrification of the factory. The plant is capable of turning out 1,200 tons of crushed ice a day and delivering it into the holds of the fishing vessels by means of a fleet of motor lorrics. Before reconstruction, the plant was driven by ponderous slow-speed engines. It has now been replaced by electrically driven compressors and all the auxiliary equipment has been completely electrified. The refrigerating medium is ammonia and the ammonia gas is raised in the compressors to a pressure of between $100 \mathrm{lb}$. and $180 \mathrm{lb}$. per sq. in. It is next cooled and liquified by passing through a condenser. The liquid then passes to the refrigerating plant in tubes surrounded by brine. The liquid. expanding to its gaseous form absorbs heat from the brine which is cooled below $0^{\circ} \mathrm{C}$. The cold brine is circulated in a large tank containing the cans which hold the pure water to be frozen. The four compressors are driven by four motors each of 600 horse power. These are supplied with electric power by the Grimsby Corporation, through a transmission line at 6,300 volts. The Ice Company is developing a new process of freezing which it is hoped will popularise frozen fish. Complaints have been made that frozen fish are 'soft' or 'mushy' when thawed. By rapidly freezing them the water between the flakes of the fish does not crystallise and when thawed it is stated that the fish is just as firm and white as fresh fish.

\section{Progress at the Indian Institute of Science, Bangalore}

ThE April number of Electrotechnics, the journal of the Electrical Engineering Society of the Indian Institute of Science at Bangalore, proves that rapid progress is being made in developing its activities. It has been decided to instal in the Electrical Department a radio frequency standard which will enable measurements to be carried out with the highest accuracy over a range extending from 10 to 24,000 kilocycles per second. The Government of India will recognise the Institute's certificates. It is hoped that this will prove the first step towards the establishment of a National Physical Laboratory of India. An obituary notice of the late Dr. Alfred Hay, who was appointed to the chair of electrical technology at the Institute in 1908, appears in this issue. Many of his students have done good work in electrical research. He was sadly missed by them when he left for England in 1923. He died in Cyprus in 1932. $\mathrm{He}$ was succeeded by Prof. J. K. Catterson-Smith, who is now Siemens professor of electrical technology at King's College, London. He did excellent work in developing radio research at Bangalore. Sir C. V. Raman became director of the Institute in succession to Dr. M. O. Forster, whose well-merited knighthood announced among the King's birthday honours will give particular pleasure to his friends. An interesting account is given of the Uhl River hydro-electric scheme. The combined output of the power stations will be 150,000 kilowatts. From an article by C. B. Sethna, director of the Bombay broadcasting service, on the progress of broadcasting in India, it appears that Calcutta, Bombay and Madras have now a regular broadcasting service. What is wanted seems to be a few high-power broadeasting stations at the centres of culture of the important linguistic areas of India.

\section{Exchange of Goods during Economic Depression}

REVFiRsions to simpler types of economic organisation are not uncommon in times of economic stress, and an interesting example is provided by the development of the exchange of goods and services by barter in the United States during the present economic depression. In 1931 a small exchange was opened in Salt Lake City to facilitate the barter of unemployed labour for surplus farm produce. Since then, the movement has spread rapidly to many parts of the country and now covers a wide range of trades and professions. A National Development Association was formed to organise the exchanges, and in July 1932 this body introduced a medium of exchange in the form of paper tokens known as 'scrip'. This 'scrip' represents to the holder the value of the produce or services he has provided and can be exchanged for an equal value of other produce, being readily accepted by traders, shops and theatres. 'The issue of 'scrip' is, however, far from being an innovation in the United States, and recently Mr. T. T. Belote, curator of history in the Smithsonian Institution, arranged an interesting exhibition of earlier examples. During the decade 1832-42, numerous bank failures led to much money being withdrawn from circulation, and to meet the monetary stringency a large number of so-called 'hardtime tokens' were issued. Some of these bore laudatory or satirical legends referring to the financial policies of Jackson or Van Buren. In the same period, many commercial firms issued a kind of token money known as 'store cards'. Up to the Civil War, paper scrip issued by banks and private firms of almost every imaginable character circulated extensively. Some of it was well-drawn and finely engraved, but so rapidly did many of the issues deteriorate in value that they came to be known as 'skin plasters'.

\section{B.D.H. Products}

WE have received from the British Drug Houses Ltd., London, N.1, leaflets describing the nature and uses of certain of their products. 'Spironine', a stable elixir, contains in each fluid drachm 3 grains of di-iodo-caffeine hydroiodide together with the soluble constituents of $7 \frac{1}{2}$ grains of coffee. It is recommended for the relief of asthma during the intermittent paroxysms. It should be given at the onset of an attack, its effect being immediate. By checking the paroxysms it prevents the development of such chronic conditions as emphysema and bronchitis. Another drug of great value in the treatment of asthma is 'Ephedrine', which also finds a place in 
the treatment of hay fever and whooping cough. Ephedrine B.D.H. is issued in tablets and in solution in ampoules, and as an elixir, an inhalant, a throatspray and a nasal jelly. 'Acriflavine B.D.' is a useful antiseptic for the treatment of wounds and local septic conditions. It can also be administered by mouth (as neutral acriflavine or euflavine in enteric coated tablets) or by intravenous injection. A new edition of the firm's vitamin booklet has also been prepared. It describes the uses in general practice of 'Radiostoleum' (vitamins A and D concentrate), 'Radio-Malt' (containing vitamins $A, B_{1}, B_{2}$, and $D$ ), 'Radiostol' (vitamin D) and 'Avoleum' (vitamin A). 'Radiostoleum' liquid is standardised to a 'blue' value of 500 by the Carr-Price test and contains 3,000 international units of vitamin D (calciferol) per gram. The capsules have a 'blue' value of 1,000 and each contains 1,200 vitamin $\mathrm{D}$ units. It is recommended as a preventive against infection and also in the prophylactic and curative treatment of rickets and osteomalacia and dental caries. 'Radiostol' solution is prepared from pure crystalline calciferol. It is standardised to contain 3,000 vitamin $D$ units per gram (B.P., 1932). 'Avoleum' is standardised to a 'blue' value of 1,000 .

\section{Pathology and Bacteriology at Leeds}

THe annual report for 1932 of the Department of Pathology and Bacteriology, University of Leeds, by Profs. M. J. Stewart and J. W. McLeod, recently issued, surveys the teaching and research work carried out in the laboratories. The research work includes investigations on industrial pulmonary diseases, studies in renal function, and on different cultural types of the diphtheria bacillus. In four hæmatite miners an extreme degree of pulmonary fibrosis was detected. In cancer research, Dr. Bonser has obtained results strongly suggesting that it is possible to breed a race of mice which respond very early to tumour induction by means of tar.

\section{The Ross Institute and Hospital for Tropical Diseases}

The annual report and accounts for 1932 of the Ross Institute and Hospital for Tropical Diseases, Putney Heath, S.W.15, records an increase in receipts of $£ 1,051$ compared with 1931 , and the net loss on the year's working is reduced to $£ 429$. Additional donations and annual subscriptions would be very welcome so that the work of the Institute may be extended, and income and expenditure may at least balance. Information is given respecting the activities of the Institute in various parts of the world, particularly in regard to anti-mosquito measures and malaria control, together with a summary of the research work conducted in the laboratories and elsewhere.

\section{Announcements}

THE Research Defence Society will hold its annual general meeting at the London School of Hygiene and Tropical Medicine, Keppel Street, London, W.C.1, on June 22 at 3 p.m., when the seventh Stephen Paget memorial lecture will be delivered by Major-
Gen. Sir Leonard Rogers on "The Saving in Life and Suffering, due to Medical and Veterinary Research, with special Reference to the Tropics".

Ww have received from Messrs. W. Watson and Sons the thirty-third edition of their catalogue of microscopic objects. The contents of this list, which are well classified, include a wide range of slides useful for teaching and demonstration purposes, and many that will appeal to the microscopist who desires slides of named species, for example. of diatoms, prepared for careful examination.

ANother volume of collected researches, published from the wards and laboratories of the London Hospital during 1932, has been issued by the Publications Committee (London: H. K. Lewis and Co., Ltd., 136 Gower Strest, W.C.1. 7s. 6d. net). The papers included, all of which have been published elsewhere, deal with many branches of the science and art of medicine and form a notable contribution to the subject.

Applications are invited for the following appointments, on or before the dates mentioned:--An assistant lecturer in mathematics at the University College of South Wales and Monmouthshire, Cardiff - The Registrar (June 12). A temporary assistant at the Mersey Laboratory of the Department of Scientific and Industrial Research-The Secretary, 16, Old Queen Street, Westminster, S.W.l (June 13). Two full-time lecturers in chemistry at the Poly. technic, Regent Street, London, W.1-The Director of Education (June 16). A lecturer in physiological chemistry at Guy's Hospital Medical School-The Dean, Guy's Hospital Medical School, London Bridge, S.E.I (June 19). A junior scientific otficer at the Fuel Research Station, East Greenwich-The Secretary, Department of Scientific and Industrial Research, 16, Old Queen Street, Westminster, London, S.W.l (June 19). A full time medical radiologist in the Western Infirmary and University lecturer in the University of Glasgow-J.-Jatheson Johnston, 87, Union Street, Glasgow (June 21). A professor of electrical engineering at University College, Nottingham--The Registrar (June 21). A principal of the Pontardawe Mining and Technical Institute and Junior Technical Day School--The Director of Education, County Hall, Cardiff (June 22). A lecturer in mathematies and an assistant lecturer in electrical engineering at the Manchester Municipal College of Technology-The Principal (July I). A professor of mathematics at the Auckland University College, New Zealand-The Secretary of the Universities Bureau of the British Empire, 88a, Gower Street, London, W.C.1 (Aug. 1). A mycologist in the Department of Plant Pathology at Rothamsted Experimental Station, Harpenden-The Secretary (Sept. 15). A professor of organic chemistry at the University of Liverpool--The Registrar. An assistant civil engineer and an assistant mechanical engineer for the Commissioners for the Port of RangoonSir Alexander Gibb and Partners, Queen Anne's Lodge, Westminster, S.W.1. 